Atıf Bilgisi: Kuzucanlı, G. ve Can, A. (2021). Use of social media in the integration process of refugees: Example of Syrian refugees living in Şanlıurfa. INIF E-Dergi, 6(2), 501-520.

\title{
USE OF SOCIAL MEDIA IN THE INTEGRATION PROCESS OF REFUGEES: EXAMPLE OF SYRIAN REFUGEES LIVING IN ŞANLIURFA*
}

\author{
Dr. Öğr. Üyesi Gökhan KUZUCANLI** \\ Prof. Dr. Aytekin CAN*** \\ DOI: 10.47107/inifedergi.977575
}

Araștırma Makalesi: $^{* * * *}$

Başvuru Tarihi: 02.08.2021

Kabul Tarihi: 08.10.2021

\begin{abstract}
The inclusion of social media platforms in our lives has made it effective in many areas. Today, individuals meet their needs such as communication, entertainment, following the news, shopping and integration through social media platforms. Social media is especially important for the integration of individuals immigrating to a different country. Individuals who have the opportunity to communicate with other individuals through social media platforms can share their feelings, thoughts, expectations and requests with the individuals they communicate with. On the other hand, thanks to social media platforms, individuals who are new to society can communicate with both the individuals of the society and the individuals who are later included in the society, and make sense of the society they have just joined by taking advantage of these platforms. In this study on Syrian refugees living in Şanlıurfa, the social media usage habits of the refugees were investigated during the integration process. In the study, the social media use of refugees whose survey technique was used was tried to be investigated in full detail. It has been determined that refugees benefit greatly from social media during the integration process, and that refugees have an integration attitude, but they feel they belong to their own culture. Among the findings of the study, participants benefited from the internet quite often. Participants stated that they use social media in order to integrate into Turkish culture. Among the findings of the study, the most used media of the participants was Turkish social media and then ethnic social media.
\end{abstract}

\section{Keywords: Social Media, Contact, Integration, Migration, Refugees, Culture}

\section{SIĞINMACILARIN ENTEGRASYON SÜRECINDE SOSYAL MEDYA KULLANIMI: ŞANLIURFA'DA YAŞAYAN SURIYELI SIĞINMACILAR ÖRNEĞİ}

$\ddot{\mathbf{O z}}$

Sosyal medya platformlarının hayatımıza dahil olması birçok alanda onu etkili kılmıştır. Bugün bireyler sosyal medya platformları aracılığı ile iletişim, eğlence haber alma, günceli takip etme, alışveriş ve entegrasyon gibi ihtiyaçlarını bu platformlar aracılığı ile gidermektedir. Özellikle farklı bir ülkeye göç eden bireylerin entegrasyonu açısından sosyal medya, büyük önem arz etmektedir. Sosyal medya platformları üzerinden diğer bireyler ile iletişime geçme firsatı bulan bireyler duygularını, düşüncelerini, beklentilerini, isteklerini iletişim kurdukları bireyler ile paylaşabilmektedir. Diğer taraftan sosyal medya platformları sayesinde topluma yeni dahil olan bireyler hem toplumun öz bireyleri ile hem de kendisi gibi topluma sonradan dahil olan bireyler ile iletişime geçebilmekte ve yeni katıldıkları toplumu, bu platformlardan faydalanarak anlamlandırabilmektedir. Şanlıurfa'da yaşayan Suriyeli sığınmacılar üzerinde gerçekleştirilen bu çalışmada entegrasyon sürecinde sığınmacıların sosyal medya kullanım alışkanlıkları araştırılmıştır.

\footnotetext{
${ }^{*}$ Bu çalışma, Selçuk Üniversitesi, Sosyal Bilimler Enstitüsü, Radyo Televizyon ve Sinema ABD’de, Prof. Dr. Aytekin Can danışmanlığında hazırlanan "Suriyeli Sı̆̆ınmacıların, Toplumsal Entegrasyon Sürecinde Sosyal Medya Araçlarını Kullanım Alışkanlıkları: Şanlıurfa Örneği” başlıklı doktora tezinden üretilmiştir.

*** Kütahya Dumlupınar Üniversitesi, E-mail: gkhn_kzcanli@hotmail.com, ORCID ID: 0000-0003-3584-0133

*** Selçuk Üniversitesi, İletişim Fakültesi, Radyo Televizyon ve Sinema Bölümü, E-mail: aytekcan@selcuk.edu.tr, ORCID ID: 0000-0002-7620-3766

***** Yazar / yazarlar, makalede araştırma ve yayın etiğine uyulduğuna ve kullanılan fikir ve sanat eserleri için telif hakları düzenlemelerine riayet edildiğine yönelik beyanda bulunmuştur.
} 
Çalışmada anket tekniği kullanılmış; sığınmacıların sosyal medya kullanımları tüm detayları ile araştırılmaya çalışılmıştır. Sığınmacıların entegrasyon sürecinde sosyal medyadan oldukça fazla faydalandıkları, sığınmacıların bütünleşme tutumu içerinde olduğu buna karşın kendilerini öz kültürlerine ait hissettikleri belirlenmiş̧ir. Katılımcıların internetten oldukça sık yararlanması da araştırmanın bulguları arasındadır. Katılımcılar sosyal medyayı Türkiye'ye entegre olmak amacıyla kullandığını belirtmiştir. Araştırmada katılımcıların en fazla kullandığı medya organının Türk sosyal medyası olduğu, ardından etnik sosyal medya olduğu araştırmanın bulguları arasındadır.

Anahtar Sözcükler: Sosyal Medya, Illetişim, Entegrasyon, Gö̧̧, Mülteci, Kültür

\section{Introduction}

In today's global world, the opportunities provided by the internet offer many conveniences to its users. Thanks to various platforms created over the internet, individuals can receive instant news from all over the world and express their opinions. In addition, individuals can collect information about places they have never been or go online and communicate with the people who live there through social media platforms. Social media sites are apps that allow members to create their own profiles, form groups as they wish, messaging members with each other, and performing various activities. (Kara, 2013, p. 60). The internet, which was difficult to reach in the early days of our lives, has entered our pockets today and has become contactable from anywhere with the developments in technology. Today, we can get news from almost anywhere in the world thanks to smartphones wherever we are.

Internet technologies called new media have put an end to expensive and limited communication and enabled more real and faster communication between cultures, countries and communities. Integration between communities with new media has become easier (Balle and Eymery, 1991, p. 95). Social media users use these sites to interact with the people they want and to meet new individuals (Ellison, vd., p. 1143). Social media enables this communication between individuals and masses to be realized quickly, conveniently and at a very low cost (Kuzucanlı and Saygin, 2021, p. 167). These developments in technology are also thought to facilitate information, communication, access to information and integration into society. As the study shows, it's not the first time we've seen refugees living in Şanlıurfa use social media platforms to meet their many needs. If we briefly mention the definitions made on social media; Social media platforms are an efficient marketing area where many potential consumers coexist and voluntarily share their personal information (Kara, 2015, p. 470).

Social media is a web-based platform that allows us to quickly share our opinions and opinions on a topic, while also allowing us to get feedback such as likes and comments (Aksakal, 2015, p. 177). Social networking sites are web-based services that allow people to perform a public or semi-public service within a limited system (Boyd and Ellison, 2007, p. 211). As can be understood from the definitions, social media platforms, unlike the elements of media called traditional media (radio, television and newspapers), allow mutual communication and allow users to create their own profile as they wish. It is known that individuals who immigrate to another country or have to emigrate benefit from social media platforms for various purposes. The concepts of migrants, refugees and asylum seekers are frequently confused. For a better life, those who leave their home countries and start living in another country, usually in order to live in better financial conditions, are called immigrants (Türk Kızılayı Göç ve Mülteci Hizmetleri Müdürlüğü, 2017, p. 1).

Refugees and asylum seekers are defined as people who have forced their way out of their countries due to wars, political repression, disasters, ethnic conflicts, etc. (Önen vd, 2014, p. 224). Although there are many opinions that there are differences between refugees and asylum seekers, the common feature of the two situations is that people leave 
their homeland by necessity. In terms of the continuity of unity, order and peace in society, it is very important that newly incorporated individuals are integrated into the existing order and that the indigenous community approaches the habits of newcomers with tolerance. Media outlets are important in terms of completing the integration process quickly and successfully.

Meeting the social and psychological needs of refugees through social media platforms, which they cannot meet normally, is of great importance in terms of adapting to society (Gülnar and Balc1, 2011, s. 36). Refugees may find it difficult to communicate face-to-face. In this process, media outlets are brought up as alternatives (Gülnar, 2011, p. 52-53). Refugees can communicate with others, especially through social media platforms that enable mutual communication. Social media has also become important when it comes to finding, recognizing, continuing to be social, knowing and searching for the rights of refugees who are far from their homeland (Gündüz and Engin, 2016, p. 48). Users who are not subjected to censorship on social media can exchange ideas freely through social media and even become effective groups with enforcement power through participation (Gündüz and Engin, 2016, p. 48).

Today, people can meet their socialization needs with social media platforms from where they sit today (Güngör, 2013, p. 125). People who meet in a virtual environment strive to adapt to the culture they are in or are new to in the real world (Güçdemir, 2012, p. 63). Social media platforms are seen as among the strongest ways for individuals to express themselves (Kuşay, 2010, p. 68). Today, socialization takes place by meeting on social media platforms and creating virtual communities (Erdal, 2013, p. 59). In terms of individuals going to different countries, it has become very simple for migrants to communicate with the locals where they are going with technological developments (Güllüpınar, 2012, p. 82). Through social media platforms, individuals can communicate for their purposes and have the opportunity to live the life they want in other societies (Uluç and Yarc1, 2018, p. 92-93). Social media is considered as a tool that contains different cultures and can interact by strengthening the intercultural influence. (Zeria, 2011, p. 131). Thanks to social media platforms, individuals can communicate with people from different regions, obtain information, go to other countries in order to realize their dreams or by necessity.

\section{Methodology}

\subsection{Application of Research and Sampling}

This research has been carried out on Syrian refugees who use social media to address the problems faced by individuals living in Şanliurfa in the position of, refugees to evaluate the integration process of refugees and to examine the role of social media in the integration process. The research consists of survey questions with likert characteristics. The surveys were randomly applied to 612 people living as refugees in Şanliurfa. In this research, the way of sampling was preferred because the universe was very wide.

\section{Data Collection Tool}

This research consists of survey questions with demographic and likert characteristics. There are 8 different scales in the study, including a total of 107 questions. All sub-scales have argument questions that can affect integration, which is evaluated as dependent changing. As a quantitative data collection tool, a survey on the "social media and social integration process" developed by the researcher was applied using previous research. 
In this study, survey questions applied by Gülnar and Balc1 to foreign students were used after the field research was carried out. The aforementioned questionnaire was tailored to Syrian refugees living in Şanlıurfa and these forms were examined by four different experts. When the questionnaires were finalized, 100 people were piloted and the current and non-valid questions were reassessed. Language problem was encountered in the pilot study. As a result, the majority of the questionnaires were translated into Arabic by two experts and the final survey questions were applied to Syrian refugees.

In this research;

1) How much and more social media platforms are used by whom,

2) The contribution of social media platforms to the socialization of refugees,

3) How, how much and for what purpose refugees use social media platforms in the process of inclusion in society,

4) Social media platforms are more usable, useful still focused on the introduction and goals. The questions were answered with the example of Syrian refugees residing in Şanlıurfa.

In order to evaluate the hypotheses that arise in this study; independent sample $t$ test, paired sample $t$ test, one-way variance analysis (ANOVA), independent sample t test and correlation analysis were used.

\subsection{Individual Differences}

In this study, individual differences were evaluated in two different groups: demographic and pre-cultural variables. The Turkish language skills of the refugees were evaluated as five $(1=$ very weak, $5=$ very strong) in a four-point question pattern that included Ying and Liese's ability to speak, read, write and understand English. Wang 2006 added the fifth item to the four substances evaluated, which measures the level of trust in the learned language. In this study, it was evaluated by Wang's five-point measurement. Ying and Liese 1990 calculated the reliability of their scale as an alpha value of .71. Wang proved the reliability of his scale with an alpha value of .88 (Gülnar and Balc1, quoted by Wang, 2011, p. 152). In this study, the alpha reliability value of the scale was calculated as .86. The structural validity of the scale was calculated as a positive correlation between language skills and social integration $(r=.381, \mathrm{p}<.001)$.

The other group of variables evaluated within the scope of the research are variables that measure pre-cultural conditions. These are the ones that are going to It specifies the number of people recognized in Turkey before settling in Turkey, the number of visits to Turkey before coming to Turkey and the number of countries visited outside Turkey.

\subsection{Cultural Attitudes}

Another argument that is likely to affect social integration, which is considered as dependent variable in this research, is cultural attitudes. Within the scope of the study, the culture attitude scale of 9 articles created by Kim was used when evaluating the attitudes of refugees towards culture. The aforementioned scale is based on three cultured behaviors under the headings of assimilation, integration, decomposition. It is measured under the articles of traditions, lifestyle and friendship. The five-way Likert (1= I Strongly Disagree, $5=$ I Strongly Agree) scale is intended to reveal the behaviors mentioned.

Kim recorded the reliability of the scale as .73 for assimilation, .76 for integration and .71 alpha for decomposition. Wang said: "I'm not going to let resulted in .49 for 
assimilation, .48 for separatism and .55 for integration (Gülnar and Balc1, quoted by Wang, 2011, p. 153). In this study, the reliability of the integration attitude was calculated as .63, the reliability of the divergence attitude was .57 and the reliability of the assimilation attitude was calculated as .57 alpha values. The structural validity of the scale was also revealed by positive correlations between social integration and integration $(r=.210, p<$ $.001)$, positive with assimilation $(\mathrm{r}=.247, \mathrm{p}<.001)$, and separation between interethnic communication behaviors $(\mathrm{r}=.112, \mathrm{p}<.001)$. In this research, cultural identity measurement was carried out in order to measure the proximity of refugees to cultural identity. On this scale of two questions, respondents found answers by rating their feelings to turkey or their country between 1 and 7. Ward and Rana-Deuba 1999, then Gülnar and Balc1 2011.

\subsection{Interpersonal Communication}

Within the framework of the interpersonal communication argument, the behavior of refugees to use the media is discussed. With the four articles, the activities of refugees to participate in the media, the frequency of participation are discussed within the framework of the migrating country and their culture. In this study, the alpha value of the scale was calculated as .49. The structure validity of the scale was calculated by positive correlation between decomposition attitude and intragroup behavior patterns $(\mathrm{r}=.112, \mathrm{p}<.001)$, and positive correlation between assimilation attitude and out-of-group behavior patterns ( $\mathrm{r}=$ $.113, \mathrm{p}<.001)$.

\subsection{Turkish Social Media Usage and Motivations}

Papacharissi and Rubin 2000, which were used by Gülnar 2011 in the study of Turkish social media use behaviors of refugees, were used by converting the scale of "internet use motivations" consisting of 27 articles into social media use. In the Gülnar (2011) study, as in Wang's research, the scale added to the factors of culturalization and reflection of values became a total of 37 questions.

In this study, alpha reliability values in the lower dimensions of the scale were calculated between .58 and .80 . The total reliability value of the scale is .935 . The structure validity of the scale, positive correlation between integration attitudes and motivation for culture $(r=.277, \mathrm{p}<.001)$, positive correlation between assimilation attitude and cultured attitude $(\mathrm{r}=.216, \mathrm{p}<.001)$, positive correlation between divergence attitude and social escape factor $(\mathrm{r}=.220, \mathrm{p}<.001)$.

\subsection{Type and Frequency of Preferred Mass Media}

In this study, the media tools and frequency of use used by refugees were examined using five scales in two different groups as the media of the country of destination and the media of their homeland ( $1=$ None, 5= Regular every day). Gülnar and Balc1 2011 developed the aforementioned scale and used the studies.

\subsection{Social Integration}

Socio-cultural adaptation, which was evaluated as dependent variable in the study, was evaluated by Ward and Kennedy's 1999 "Sociocultural Adaptation Scale". The aforementioned scale was also developed and used by Gülnar and Balc1 2011. The scale previously used in different researches was adapted to this research and evaluated through the participants. With the scale mentioned, it is aimed to show how difficult it is for the participants to carry out their activities related to social life. Participants reported their difficulty through a five-scale ( $1=$ Very difficult, $5=$ Very Easy). Ward and Kennedy 1999 rated the scale's alpha reliability ranged from .75 to .91 . In this research; the reliability 
value of the scale is recorded as .94 . In the study, the structure validity of the scale was supported by the positive correlation between social integration and feeling belonging to Turkish identity $(\mathrm{r}=.209, \mathrm{p}<.001)$ and positive correlation with Turkish proficiency level $(\mathrm{r}=.381, \mathrm{p}<.001)$.

\section{Results}

\subsection{Socio-Demographic Characteristics of Refugees Participating in the Study}

$56.9 \%$ of the participants were male and $43.1 \%$ were women. $43.2 \%$ of the participants were individuals between the ages of 22 and 27. 35.4\% of the participants were recorded as $16-21,17.0 \%$ as $28-35$ and $4.4 \%$ in the age range of 35 and older. The mean age of the participants was 24.46. This result was reached through central trend statistics. According to the central trend statistics results regarding the duration of the participants' presence in Turkey, it was concluded that the duration of the participants in Turkey was at least 1 year and the maximum was 9 years. The average duration of participants' stay in Turkey was recorded as 3.82 years. $99.5 \%$ of the participants stated that they were Muslim, $0.3 \%$ were Christian and $0.2 \%$ were atheists.

When the residency methods of the participants were examined, the proportion of those who stayed with their family was recorded as 39\%, the proportion of those who stayed at home with their friends was $19.9 \%$, the proportion of those who stayed in the dormitory was $23.5 \%$, and the proportion of those who were alone in the house was recorded as $16.7 \%$. $66.3 \%$ of respondents stated that they were students, $23.4 \%$ were unemployed and $10.4 \%$ said they were working a job. $87.8 \%$ of respondents stated that they were syrian citizens only, $4.2 \%$ were Kuwaiti, $5.6 \%$ were Iraqi and $2.4 \%$ were Palestinian citizens. It is thought that $12.2 \%$ of the participants have dual citizenship.

\subsection{Field Survey Findings on Social Integration Levels of Syrian Refugees}

Under this heading, participants' levels of social integration were determined through frequency analysis and central trend statistics.

Table 1. Percentage Distribution of Participants' Social Integrations

\begin{tabular}{|c|c|c|c|c|c|c|}
\hline & 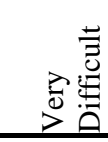 & 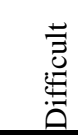 & $\begin{array}{l}\stackrel{0}{\tilde{z}} \\
\dot{z} \\
\end{array}$ & 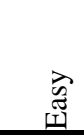 & $\begin{array}{l}\widehat{a} \\
\overrightarrow{\tilde{I}} \\
\overrightarrow{0} \\
\overrightarrow{0}\end{array}$ & 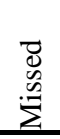 \\
\hline Making friends & 17.8 & 20.8 & 27.0 & 20.3 & 12.9 & 1.3 \\
\hline Using transportation systems & 5.1 & 16.0 & 32.8 & 30.2 & 14.1 & 1.8 \\
\hline To be able to express yourself & 3.4 & 12.3 & 39.4 & 30.1 & 13.4 & 1.5 \\
\hline Adapting to the pace of life & 4.1 & 14.2 & 31.5 & 34.2 & 14.4 & 1.6 \\
\hline Go shopping & 3.9 & 14.1 & 26.8 & 33.3 & 19.6 & 2.3 \\
\hline Join social communities (meetings) & 11.6 & 17.2 & 28.3 & 26.8 & 11.9 & 4.2 \\
\hline Talk to others about yourself & 5.4 & 19.1 & 28.9 & 31.7 & 12.3 & 2.6 \\
\hline Understanding jokes and humor & 4.9 & 16.8 & 31.7 & 31.0 & 13.2 & 2.3 \\
\hline Find your favorite foods & 4.7 & 10.3 & 31.0 & 34.0 & 17.6 & 2.3 \\
\hline
\end{tabular}




\begin{tabular}{|c|c|c|c|c|c|c|}
\hline Complying with laws and rules & 5.7 & 13.4 & 32.4 & 30.6 & 16.0 & 2.0 \\
\hline $\begin{array}{l}\text { Engaging with people who represent authority, such } \\
\text { as the police }\end{array}$ & 8.8 & 11.9 & 35.6 & 26.8 & 14.9 & 2.0 \\
\hline Engaging with bureaucracy & 9.5 & 17.0 & 29.9 & 27.3 & 13.9 & 2.5 \\
\hline $\begin{array}{l}\text { Joining/working together in non-governmental } \\
\text { organizations }\end{array}$ & 7.8 & 14.9 & 33.2 & 27.3 & 15.0 & 1.8 \\
\hline $\begin{array}{l}\text { Communicating with people from different ethnic } \\
\text { groups }\end{array}$ & 8.2 & 14.9 & 32.0 & 28.9 & 14.5 & 1.5 \\
\hline Engaging with members of the opposite sex & 8.3 & 17.6 & 32.0 & 28.3 & 12.3 & 1.5 \\
\hline Take a stand against service that doesn't please you & 7.5 & 18.1 & 33.2 & 27.5 & 11.6 & 2.1 \\
\hline Being able to find your way (your way) in traffic & 6.5 & 15.7 & 32.8 & 29.9 & 12.6 & 2.5 \\
\hline Adapting to climatic conditions & 6.4 & 14.7 & 29.2 & 30.2 & 17.2 & 2.3 \\
\hline $\begin{array}{l}\text { Engaging with people who look at you carefully } \\
\text { (upright) }\end{array}$ & 6.2 & 15.2 & 34.3 & 30.9 & 11.6 & 1.8 \\
\hline $\begin{array}{l}\text { Living away from family members (outside the } \\
\text { country) }\end{array}$ & 8.3 & 13.9 & 32.7 & 30.9 & 11.8 & 2.5 \\
\hline Engaging (communicating) with older people & 5.9 & 17.2 & 27.9 & 35.0 & 11.4 & 2.6 \\
\hline $\begin{array}{l}\text { Understand what you're being asked to do at school/at } \\
\text { work }\end{array}$ & 7.4 & 14.7 & 28.8 & 35.6 & 11.8 & 1.8 \\
\hline $\begin{array}{l}\text { Developing relationships with Turks in } \\
\text { school/workplace }\end{array}$ & 7.8 & 17.2 & 26.6 & 33.7 & 12.9 & 1.8 \\
\hline Express your thoughts freely at school/workplace & 6.4 & 14.1 & 35.0 & 31.4 & 11.3 & 2.0 \\
\hline Accepting/understanding the Turkish political system & 9.0 & 12.3 & 33.2 & 31.5 & 12.4 & 1.6 \\
\hline Adopting the Turkish perspective in culture & 6.7 & 15.5 & 36.1 & 25.2 & 14.4 & 2.1 \\
\hline Understanding the Turkish value system & 5.7 & 19.3 & 31.9 & 27.8 & 13.4 & 2.0 \\
\hline $\begin{array}{l}\text { To be able to evaluate events from a Turkish } \\
\text { (Turkey) point of view }\end{array}$ & 5.4 & 15.4 & 36.1 & 26.0 & 15.5 & 1.6 \\
\hline Understanding cultural differences & 5.2 & 14.5 & 32.0 & 29.7 & 17.2 & 1.3 \\
\hline $\begin{array}{l}\text { To be able to see both sides of intercultural issues } \\
\text { (Turkish/your own country) }\end{array}$ & 7.7 & 15.4 & 29.7 & 28.3 & 18.3 & 0.7 \\
\hline
\end{tabular}

According to the frequency analysis results of the survey questions related to the social integration of the participants; in terms of refugees, it is seen that they easily achieve 
activities such as understanding what is being asked of them in school/workplace, communicating with elderly people, developing relationships with Turks at school/workplace, going shopping, finding the food they love and adapting to the pace of life. On the other hand, making friends, joining social communities, taking a stand against service that does not please them, and engaging with members of the opposite sex have been identified as the issues where refugees have the most difficulty.

When the respondents' answers to the aforementioned questions were sorted from easy to difficult, they considered the activities of going shopping, finding the food they liked, adapting to the pace of life, understanding cultural differences, and following the laws and rules as easy for refugees. The issues of making friends, joining social communities, taking a stand against service that does not please them, and engaging with members of the opposite sex have been identified as the most difficult issues for refugees.

Table 2. Central Trend Statistics on Integration Levels of Syrian Refugees

\begin{tabular}{l|lllll}
\hline & $\mathrm{N}$ & Lowest & Highest & $\begin{array}{l}\text { Arithmetic } \\
\text { Average }\end{array}$ & $\begin{array}{l}\text { Standard } \\
\text { Deviation }\end{array}$ \\
\hline Adaptation & 612 & 1,00 & 5,00 & 3,286 & 0,661 \\
\hline
\end{tabular}

The five-likert scale was used when measuring. The lowest value on the scale is 1 point and the highest value is 5 points. $(1.00-1.80=$ very low; $1.81-2.60=$ low; $2.61-3.40=$ medium; $3.41-4.20=$ high; $4.21-5.00=$ very high). According to the central trend statistics of the participants' social integration levels, the average level of social integration of refugees is $=3.28$. This average $(=3.28)$ indicates that the social integration of participants is "moderate".

Table 3. Frequency Distribution of Integration Levels of Syrian Refugees living in Sanliurfa

\begin{tabular}{llll}
\hline & Frekans & Percent & Current Percent \\
\hline Too Low & 11 & 1,8 & 1,8 \\
Low & 62 & 10,1 & 10,2 \\
Middle & 291 & 47,5 & 47,7 \\
High & 201 & 32,8 & 33,0 \\
Too High & 45 & 7,4 & 7,4 \\
Total & 610 & 99,7 & 100,0 \\
Missed & 2 & 0,3 & \\
\hline Generel Total & 612 & 100,0 & \\
\hline
\end{tabular}

The table shows the results of frequency analysis of participants' levels of social integration. It was determined that $47.5 \%$ of the participants had moderate integration levels, $32.8 \%$ were high, $10.1 \%$ were low, $1.8 \%$ were very low and $7.4 \%$ were very high.

\subsection{Field Research Findings on Factors Affecting Social Integration}

\subsubsection{Cultural Attitudes and Integration}

In this study, the attitudes and feelings of belonging of refugees are treated as interconnected variables. 


\subsubsection{Cultured Attitudes and Social Integration}

According to the central trend statistics results of the participants' social integration attitudes, the attitude in which refugees participated at the highest level was integration (= $3.33)$, the second was decomposition $(=2.91)$ and the last was assimilation $(=2.70)$. Participants were also supported by the $\mathrm{T}$ Test (One sample $\mathrm{t}$ test) of their cultured attitudes. In the analysis, the average of the integration attitude with a test value of 3.33 was taken. According to the study, assimilation $(\mathrm{t}=-17.54, \mathrm{p}<.000)$ and decomposition $(\mathrm{t}=$ $-12.06, \mathrm{p}<.000)$ attitudes were audited. The study found that refugees tended to be of the highest value to integration behavior.

Table 4. Correlation Analysis Results on Culturalization Attitudes and Social Integration Relationship of Syrian Refugees

\begin{tabular}{llll}
\hline & Integration & Decomposition & Assimilation \\
\hline Adaptation & $.210^{* *}$ & .194 & $.247^{* *}$ \\
\hline $\mathrm{N}$ & 612 & 612 & 612 \\
\hline
\end{tabular}

Not: $* * \mathrm{p}<.01, * \mathrm{p}<.05$

According to the correlation analysis, a significant correlation of positive weak force was found between the social integrations of refugees and their integration attitudes. $(\mathrm{r}=.210, \mathrm{p}<.01)$. A positive weak force relationship was found between adaptation and assimilation attitude.

\subsubsection{Cultural Identity and Integration into Turkish Culture}

Table 5. Cultural Identity Levels of Syrian Refugees

\begin{tabular}{l|lllll}
\hline & $\mathrm{N}$ & Lowest & Highest & $\begin{array}{l}\text { Arithmetic } \\
\text { Average }\end{array}$ & $\begin{array}{l}\text { Standard } \\
\text { Deviation }\end{array}$ \\
\hline Feeling Belonging to Turkish Culture & 606 & 1,00 & 7,00 & 4.35 & 1.66 \\
\hline Feeling Ethnically Charged & 604 & 1,00 & 7,00 & 5.02 & 1.75 \\
\hline
\end{tabular}

In the study, the participants' feelings of their own culture $(=5.02)$ were determined, while the levels of feeling belonging to Turkish culture $(=4,35)$ were determined. According to the research, refugees have a high rate of feeling belonging to their own culture.

Participants' culture-based feelings levels were also tested through the t-test. According to the results, the levels of feeling close to the self-culture of refugees $(=5.02)$ were determined as the rates of feeling belonging to Turkish culture $(=4.35)$ and it was tested once again that the refugees had a higher sense of belonging to their culture.

Table 6. Results of Correlation Analysis of Cultural Identity Belongings and Social Integration Relationship of Syrian Refugees

\begin{tabular}{|c|c|c|c|}
\hline & $\begin{array}{l}\text { Feeling } \\
\text { Culture }\end{array}$ & Belonging to Turkish & Feeling Ethnically Charged \\
\hline Adaptation & & $.209 * *$ & .056 \\
\hline $\mathrm{N}$ & & 606 & 604 \\
\hline
\end{tabular}


positively positive relationship between the adaptations of refugees and their level of cultural identity, a meaningful relationship with weak force $(r=.209) .(p<.001)$. is determined. However, no significant corral between adaptation and feeling belonging to ethnic culture was detected $(\mathrm{p}<.05)$.

\subsection{Communication and Adaptation}

Under this heading, the communication preference of the participants and the effect of this preference on integration were evaluated in the integration process.

\subsubsection{Interpersonal Communication and Social Integration}

Participants were found to speak in Turkish and their own languages, and their participation rates in cultural activities belonging to Turkey and its own nation were determined.

Table 7. Matched Sample T Test Results on Interpersonal Communication Behaviors of Refugees

\begin{tabular}{l|lllc}
\hline & $\bar{X}$ & $\begin{array}{l}\text { Average } \\
\text { Difference }\end{array}$ & t Value & Sig. \\
\hline Speaking Turkish & 2.90 & -429 & -5.958 & .000 \\
Speaking in your own language & 3.33 & & & \\
Attending Turkish cultural events & 2.93 & -.159 & -2.681 & .008 \\
Participate in cultural events of your own nation & 3.09 & & & \\
\hline Host interpersonal communication (general) & 2.93 & & & \\
\hline Interethnic communication(general) & 3.17 & & & \\
\hline
\end{tabular}

The frequency with which refugees use their own language $(=3.33)$ and the frequency with which they use Turkish $(=2.90)$ are determined. Participants stated that they preferred to use their own language more.

The participation rate of refugees in cultural events belonging to their own nation $(=3.09)$ and participation rates in Turkish cultural events $(=2.93)$ were determined. Refugees stated that they are more likely to participate in activities of their culture.

The rate at which refugees communicate with individuals of their own identity (= $3.17)$ is determined as the rate of contact with the host persons $(=2.93)$.

Table 8. Correlation Analysis Results Between Inter-Individual Communication Behaviors and Social Integration of Refugees

\begin{tabular}{l|lc}
\hline \multirow{2}{*}{ Adaptation } & Host Interpersonal Communication & Interethnic Communication \\
\cline { 2 - 3 } & $.327^{* *}$ & $.398^{*}$ \\
\hline
\end{tabular}

Not: $* * \mathrm{p}<.01, * \mathrm{p}<.05$

According to the findings of the study, a positive, weak strength and significant ( $\mathrm{r}=$ $.327 ; \mathrm{p}<.001)$ relationship was found between the participants' adaptation levels and host interpersonal communication behaviors. A positive, weak and meaningful relationship ( $\mathrm{r}=$ 
$.398 ; \mathrm{p}<.05)$ was determined between adaptation and interpersonal communication behaviors with people of their own nationality.

\subsubsection{Mass Communication Tools and Social Integration}

Table 9. Weekly Turkish Media and Ethnic Media Usage Frequency of Participants

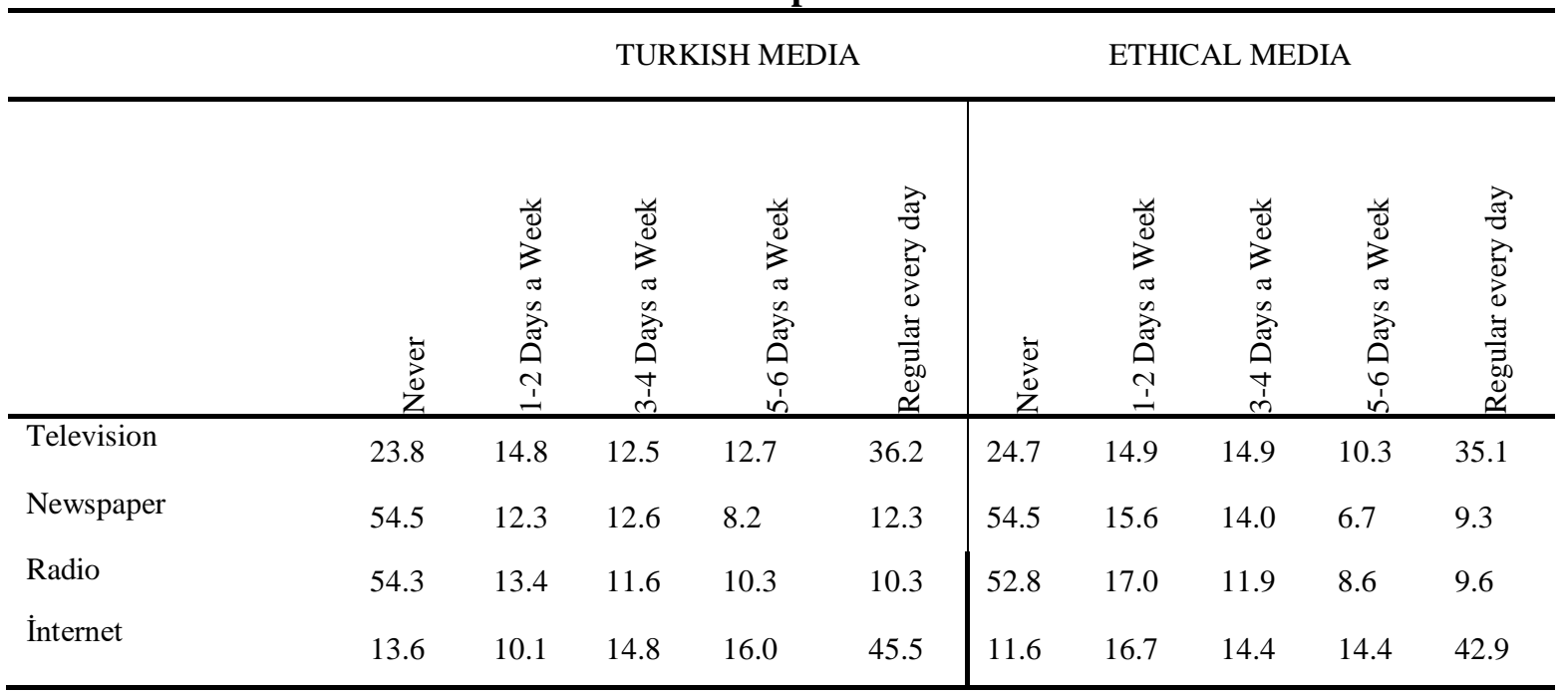

When the table about the attitudes of the participants to follow the media is evaluated; $23.8 \%$ of respondents stated that they never followed Turkish television, $14.8 \%$ followed 1-2 days a week, $12.5 \%$ followed 3-4 days a week, $12.7 \%$ followed 5-6 days a week, and $36.2 \%$ followed regularly every day. When the participants evaluated their attitudes to use television channels belonging to their own countries; $24.7 \%$ stated that they never follow their country's television channels, $14.9 \%$ follow 1-2 days a week, $14.9 \%$ follow 3-4 days a week, $10.3 \%$ follow 5-6 days a week, and $35.1 \%$ follow regularly every day.

When the behavior of the participants to follow the newspapers is evaluated; While $54.5 \%$ stated that they never followed Turkish newspapers, $12.3 \%$ stated that they regularly follow Turkish newspapers 1-2 days a week, 12.6\% 3-4 days a week, 8.2\% 5-6 days a week, $12.3 \%$ every day. When evaluated for the behavior of following newspapers belonging to their own countries; $54.5 \%$ of respondents reported that they never followed newspapers belonging to their home countries, while $15.6 \%$ stated that they regularly follow newspapers belonging to their home countries 1-2 days a week, 14.0\% 3-4 days a week, 6.7\% 5-6 days a week and 9.3\% daily.

When the radio listening behaviors of the participants are evaluated; $54.3 \%$ of the participants stated that they never followed Turkish radio channels, $13.4 \%$ followed 1-2 days a week, $11.6 \%$ followed 3-4 days a week, 10.3\% followed 5-6 days a week, and the remaining $10.3 \%$ followed them regularly every day. When the attitudes of the participants to follow the radio channels of their countries are evaluated; $52.8 \%$ of respondents stated that they never followed, $17.0 \%$ followed 1-2 days a week, $11.9 \%$ followed 3-4 days a week, $8.6 \%$ followed 5-6 days a week, and 9.6\% followed regularly every day.

Within the scope of this research, the attitudes of the participants to use the internet were examined. $13.6 \%$ of respondents reported that they never used the internet to keep track of what was happening in Turkey, to make friends, to meet their personal needs, while $10.1 \%$ reported using the internet regularly 1-2 days a week, 14.8\% 3-4 days a week, $16.0 \%$ 5-6 days a week, and the remaining $45.5 \%$ regularly used the internet every day. 
Internet usage rates for participants to keep track of what is happening in their home countries; $11.6 \%$ never, $16.7 \%$ answered 1-2 days a week, $14.4 \%$ 3-4 days a week, $14.4 \%$ 3-4 days in week, and the remaining $42.9 \%$ answered that I follow regularly every day.

Table 10. Matched Sample t-test Results for Determining Differences Between Participants' Weekly Turkish Media and Ethnic Media Use

\begin{tabular}{llllll}
\hline & Turkish Media & Ethical Media & Average Difference & t-value & Sig. \\
\hline Television & 3.24 & 3.18 & 0.63 & .986 & .325 \\
Newspaper & 2.11 & 2.01 & 0.09 & 2.14 & .033 \\
Radio & 2.10 & 2.05 & 0.53 & 1.04 & .295 \\
Social Media & 3.72 & 3.60 & .117 & 1.67 & .095 \\
\hline GENERAL & 2.80 & 2.72 & 0.80 & 2.506 & .012 \\
\hline
\end{tabular}

According to the research, the most frequently used media of the participants is Turkish social media. This is followed by ethnic social media, Turkish television and ethnic television. Participants benefited more frequently from Turkish newspapers $(=2.11)$ than ethnic newspapers $(=2.01)$. In addition, participants' overall use of Turkish media (= $2.80)$ was higher than ethnic media use $(=2.72)$.

According to the results of correlation analysis of the types of mass media and integration relationship used by the participants; positively significant relationship between the adaptation levels of the participants and the use of host mass media were determined only related to radio use. Positive, very weak force $(r=.097)$ and significant correlation between adaptation and Turkish media use were determined. No significant corral was found between the participants' adaptation levels and their behavior in using ethnic media.

\subsubsection{Social Media Use Motivations Culture and Social Integration}

When the motivations of Syrian refugees living in Şanliurfa are evaluated, it is seen that the refugees use Turkish social media sites to learn about what is happening in their countries, the world and Turkey, to obtain information about school and workplace and to learn about developments in Turkey. When looking at the dimension of culture for the reasons why refugees use Turkish social media sites, mostly refugees have stated that they use social media to integrate into Turkish society. Refugees have stated that they mostly use Turkish social media to improve their Turkish language, to understand the way Turks think and to understand Turkish culture. When the extent of social interaction is taken into consideration in the use of Turkish social media sites by refugees, refugees have reported that they use Turkish social media to make new friends, to share through social media, to meet people who think like them. One of the reasons refugees use social media is to entertainment themselves in their leisure time. Like many people who spend time on social media, refugees spend time on social media to play games, listen to music and have fun on various platforms. The last of the reasons why the refugees evaluated in the study use Turkish social media is the purpose of social escape. According to the findings of the study, refugees also use Turkish social media platforms to get away from the problems of daily life for a while. 
Table 11. Difference in Motivations for Social Media Use by Gender

\begin{tabular}{|c|c|c|c|c|c|c|}
\hline MOTIVATION & Gender & $N$ & $\bar{X}$ & $S D$ & t-value & Sig. \\
\hline Search for Information & $\begin{array}{l}\text { Men } \\
\text { Women }\end{array}$ & $\begin{array}{l}327 \\
248\end{array}$ & $\begin{array}{l}3.25 \\
3.37\end{array}$ & 573 & -2.103 & .036 \\
\hline $\begin{array}{l}\text { Culturalization/Value } \\
\text { Reflection }\end{array}$ & $\begin{array}{l}\text { Men } \\
\text { Women }\end{array}$ & $\begin{array}{l}327 \\
248\end{array}$ & $\begin{array}{l}3.27 \\
3.35\end{array}$ & 573 & -1.345 & .179 \\
\hline Social Interaction & $\begin{array}{l}\text { Men } \\
\text { Women }\end{array}$ & $\begin{array}{l}327 \\
248\end{array}$ & $\begin{array}{l}3.31 \\
3.38\end{array}$ & 573 & -1.325 & .186 \\
\hline $\begin{array}{l}\text { Entertainment/Leisure } \\
\text { Assessment }\end{array}$ & $\begin{array}{l}\text { Men } \\
\text { Women }\end{array}$ & $\begin{array}{l}327 \\
248\end{array}$ & $\begin{array}{l}3.28 \\
3.31\end{array}$ & 573 & -.556 & .578 \\
\hline Social Escape & $\begin{array}{l}\text { Men } \\
\text { Women }\end{array}$ & $\begin{array}{l}327 \\
248\end{array}$ & $\begin{array}{l}3.28 \\
3.35\end{array}$ & 573 & -1.256 & .210 \\
\hline
\end{tabular}

Differences in social media use by gender of refugees according to t test results; refugees internet use for information search purposes differs significantly $(\mathrm{t}=-2,103 ; \mathrm{p} .=$ $573 ; \mathrm{p}<.05)$. It has been found that women prefer social media more during their time in Turkey than men with the purpose of finding information. There was no meaningful relationship between the motivations and gender in the table.

Table 12. Social Media Usage Motivations and Adaptation, Language Skills, Correlation Analysis Findings Between Interpersonal Communication Behaviors

\begin{tabular}{|c|c|c|c|c|c|}
\hline & 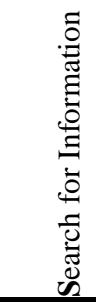 & 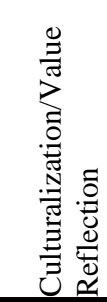 & 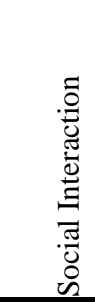 & 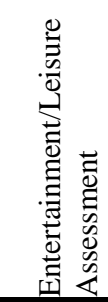 & 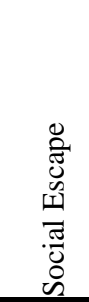 \\
\hline Adaptation & $515 * *$ & $486^{* *}$ & $495 * *$ & $483 * *$ & $438 * *$ \\
\hline Language Skills & $351 * *$ & $237 * *$ & $312 * *$ & $238 * *$ & $264 * *$ \\
\hline Speaking Turkish & $263 * *$ & $255^{* *}$ & $190 * *$ & $280 * *$ & $221 * *$ \\
\hline Speaking in Your Own Language & $333^{*}$ & $177 * *$ & $244 * *$ & $238 * *$ & $248 * *$ \\
\hline Participating in Turkish Cultural Events & 067 & $164 * *$ & $106 * *$ & $082 *$ & $098^{*}$ \\
\hline Participating in Cultural Events belonging to Their Own Nation & $82 * *$ & $173 * *$ & $164 * *$ & $167 * *$ & $135^{* *}$ \\
\hline Host Interpersonal Communication Behaviors & $192 * *$ & $261 * *$ & $173 * *$ & $214 * *$ & $196 * *$ \\
\hline Interethnic Communication Behaviors & $337 * *$ & $228 * *$ & $266 * *$ & $263 * *$ & $248^{* *}$ \\
\hline
\end{tabular}

According to the results of the correlation analysis between the motivations of refugees to use social media and their language proficiency, host and interethnic communication behaviors; there are positive, meaningful correlations between all 
motivations and language proficiency and frequency of interpersonal communication behavior.

Table 13. Correlation Analysis Findings Between Social Media Use Motivations and Culturalization Attitudes (Pearson r)

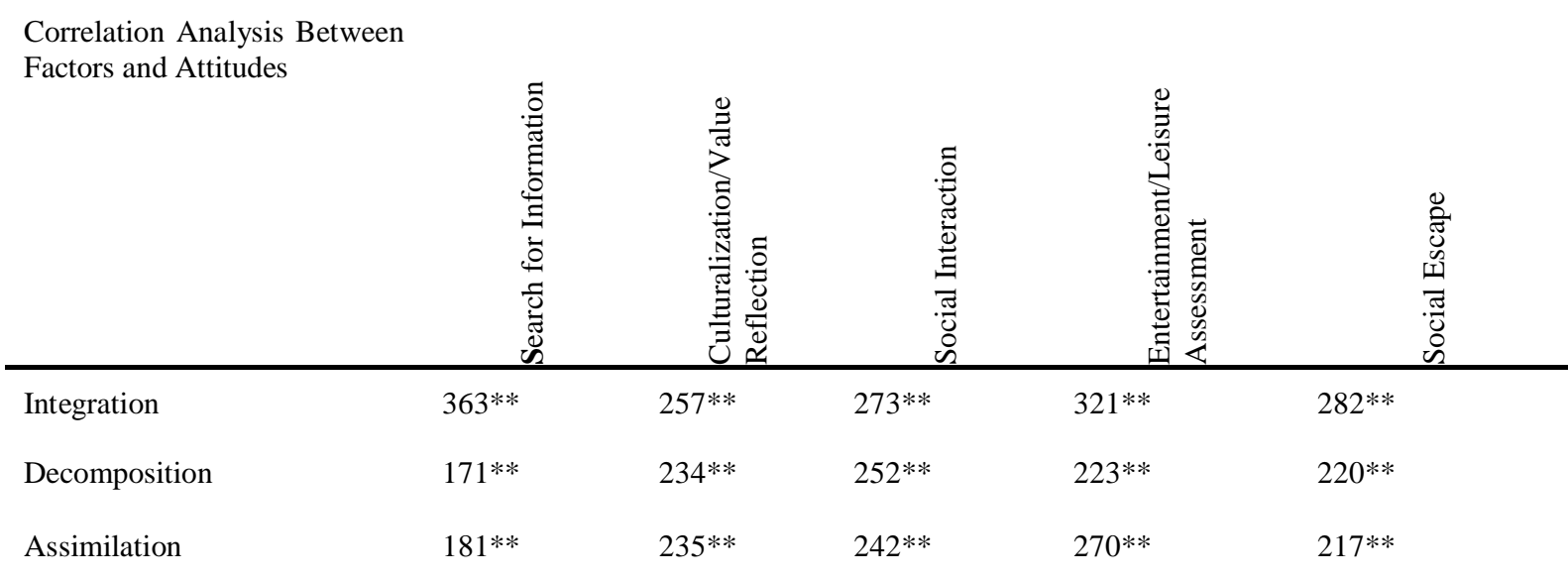

Not: $* * \mathrm{p}<.01, * \mathrm{p}<.05$

When we looked at the link between the motivations of refugees to use social media and their cultured attitudes, it was determined that there was a positive meaningful relationship between all motivations and cultured attitudes. It has been determined that there is a positive, weakly significant relationship between the motivation of culture and attitudes of integration, decomposition and assimilation. According to the findings, as the attitudes of the refugees participating in the study towards integration strengthen, the satisfaction they provide from Turkish social media sites in the direction of culture increases. In the same way, as the satisfaction provided by the participants in the direction of culture from Turkish social media sites increases, their attitudes towards assimilation increase.

\subsection{Individual Differences and Social Integration}

In this topic, the so-called demographic and precultural variables are evaluated.

\subsubsection{Demographic Variables}

In order to determine the gender adaptation levels of refugees, the responses of the refugees were subjected to an independent sample test. According to the results, the adaptation status of women $(=3.32)$ is greater than that of men $(=3.29)$. However, these results do not make sense.

There was also no relationship between the ages of the refugees and integration. According to correlation analysis; there is no meaningful relationship between the length of time refugees stay in Turkey and the levels of social integration.

\subsubsection{Turkish Competence and Social Integration Relationship}

Table 14. Central Trend Statistics on Turkish Levels of Refugees

\begin{tabular}{l|lcccc}
\hline Language Skills & $\mathrm{N}$ & Lowest & Highest & $\begin{array}{l}\text { Arithmetic } \\
\text { Average }\end{array}$ & $\begin{array}{l}\text { Standard } \\
\text { Deviation }\end{array}$ \\
\hline Reading Turkish & 604 & 1.0 & 5.0 & 2.94 & 1.31 \\
Writing in Turkish & 596 & 1.0 & 5.0 & 2.96 & 1.16 \\
Understanding Turkish & 597 & 1.0 & 5.0 & 3.16 & 1.11 \\
\hline
\end{tabular}




\begin{tabular}{l|ccccc}
\hline Speaking Turkish & 596 & 1.0 & 5.0 & 3.15 & 1.06 \\
General Trust & 566 & 1.0 & 5.0 & 3.27 & 1.18 \\
\hline Language General (Compute) & 605 & 1.0 & 5.0 & 3.08 & .943 \\
\hline
\end{tabular}

According to the findings of the study; the arithmetic average of turkish language proficiency of refugees ranges from $=2.94$ to $=3.27$. These findings explain that the Turkish proficiency of the refugees residing in Şanliurfa is "moderate".

Table 15. Correlation Analysis Results for Turkish Competence and Social Integration Relationship

\begin{tabular}{llllllll}
\hline & Reading & Writing & Understanding & Speaking & $\begin{array}{l}\text { General } \\
\text { Trust }\end{array}$ & $\begin{array}{l}\text { Language } \\
\text { (Compute) }\end{array}$ & General \\
\hline Adaptation & $.329^{* *}$ & $.332^{* *}$ & $.318^{* *}$ & $.260^{* *}$ & $.283^{* *}$ & $381^{* *}$ \\
\hline $\mathrm{N}$ & 604 & 596 & 597 & 596 & 566 & 605 \\
\hline
\end{tabular}

Not: $* * \mathrm{p}<.01$

In the study, correlation analysis was carried out to reveal the relationship between the social integration of refugees and their language levels. In the analysis, a positively significant relationship between social integration and language level was determined. A positive, weak, significant relationship was found between social integration and turkish reading level $(\mathrm{r}=.329)$, Turkish writing level $(\mathrm{r}=.332)$, level of understanding of spoken Turkish $(\mathrm{r}=.318)$, Turkish speaking level $(\mathrm{r}=.260)$, level of trust in Turkish in general $(\mathrm{r}=$ $.283)$, and general Turkish level $(\mathrm{r}=.381)$. According to these results, there is a positive relationship between integration and host language level.

One-way variance (ANOVA) analysis was applied to determine the work/education status variable. According to the results, the adaptation levels of refugees did not differ significantly according to their work/education status.

\subsubsection{Pre-Culturalization and Adaptation to Turkey}

In this part of the research, the variables "number of friends recognized in Turkey before coming to Turkey", "number of visits to Turkey before coming to Turkey" and "number of visits to other foreign countries" are included.

\subsubsection{The Relationship Between The Number of Friends Recognized in Turkey and Integration Before Coming to Turkey}

The number of friends recognized in Turkey before the arrival of refugees in Şanliurfa was evaluated. Frequency analysis was used when making this evaluation. According to the results; $64.3 \%$ of refugees stated that they did not know anyone in Turkey before coming to Turkey, while $28.8 \%$ stated that they knew 1-10, 4.4\% 11-20\% and $2.5 \%$ 21 and above. The number of people refugees knew in Turkey before coming to Turkey was also evaluated through central trend statistics and the average number of people recognized was determined as $=2.52$. After the number of people recognized in Turkey was determined, the relationship between the number of friends and compliance was tested. According to the results of correlation analysis; a positive and very weakly significant relationship $(\mathrm{r}=.094 ; \mathrm{p}<.05)$ was found between compliance and the number of people recognized in Turkey before coming to Turkey. 


\subsubsection{Number of Visits to Turkey and Integration}

It was subjected to frequency analysis of the number of visits made by refugees to Turkey before coming to Turkey. According to the findings; $88.6 \%$ of refugees stated that they had never been to Turkey before, 7.0\% were in Turkey 1-2 times, 3.0\% 3-4 times, and $1.5 \%$ were in Turkey 5 times or more. According to the results, the majority of refugees have never been to Turkey before.

According to the results of the central trend statistics; The number of visits made by refugees to Turkey before coming in Turkey varies between 0 and 10. The average number of visits $=0.28$ was determined to be at a low level. According to correlation analysis; there is no correlation between the number of visits made by refugees to Turkey before coming to Turkey and their compliance ( $p>.05$;).

The number of visits made by refugees to countries other than Turkey has been subjected to frequency analysis. According to the findings; $79.7 \%$ of refugees stated that they did not go to any country other than Turkey, $13.1 \%$ visited $1-2$ countries, $3.6 \%$ visited 3-4 countries and $3.6 \%$ visited 5 or more countries. According to the results; a significant number of refugees have not been in any country other than Turkey. When the central trend statistics for the number of countries where refugees go outside Turkey are evaluated; the number of countries visited by refugees outside Turkey varied between 0 and 30. The average number of visits was $=0.66$. According to the results of correlation analysis; a relationship between compliance and the number of refugees going to different countries except Turkey has not been determined.

\section{Conclusions}

Today, social media seems to have proven its importance and strength. Social media seems to be very effective, both in terms of integration, in terms of sanctions, in terms of reaching far away, etc. It is also understood from the research that; Syrian refugees living in Turkey benefit greatly from social media platforms for different purposes. Again, according to the conclusion drawn from the research, social media platforms are very important in the integration process and should be used effectively.

According to the study, a significant number of Syrian refugees do not speak Turkish. Assuming that millions of Syrian refugees live in Turkey, they try to meet their needs among themselves and speak their own language. Another conclusion of the study is that the vast majority of Syrian refugees living in Turkey have low levels of education. Assuming that refugees will not return to their countries, the importance of investing in the education of refugees will once again be understood. It is thought that social media can play an important role in the education of refugees.

As the study shows, refugees benefit from social media for different purposes. The internet is the most preferred of mass media. The study found that the most difficult situation for Syrian refugees in the integration process was making friends and joining social communities. This has many effects such as not being able to speak Turkish, cultural difference, living with relatives of their own families, spending more time with the people of their own country, etc., as the most important functions of social media include making friends and socializing. Considering that social media communication is easier and more encouraging than face-to-face communication, it is thought that the problems of not being able to make friends and socialize experienced by refugees will be significantly overcome through social media.

Considering the position of social media today, it will be seen that it is very important in terms of the integration of new people to our country. It is thought that having 
automatic language translation on social media platforms will contribute to integration. In this study, it was aimed to be the source of the studies to be carried out in terms of social media use and integration of refugees, and for this purpose it was carried out in Şanliurfa, one of the provinces that hosts the most Syrian refugees.

\section{Genişletilmiş Özet}

Bu araştırma, Şanlıurfa'da yaşayan sı̆̆ınmacıların gündelik hayatta karşılaştıkları problemleri ele almak, sığınmacıların entegrasyon sürecini değerlendirmek ve sosyal medyanın entegrasyon sürecindeki rolünü incelemek amacıyla gerçekleştirilmiştir. Araştırma, likert tipi anket sorularından oluşmaktadır. Oluşturulan anket soruları Şanlıurfa'da sığınmacı konumunda yaşayan bireylere rastgele örnekleme yoluyla belirlenen 612 kişiye uygulanmıştır.

Araştırmada toplam 107 soruyu içeren 8 farklı ölçek bulunmaktadır. Tüm alt ölçekler de bağımlı değișen olarak değerlendirilen entegrasyonu etkilemesi mümkün olan bağımsız değişken soruları yer almaktadır.

Araştırmada nicel veri toplama aracı olarak, daha önce yapılmış araştırmalardan elde edilen ve araştırmacı tarafından geliştirilen "sosyal medya ve toplumsal entegrasyon süreci” ile ilgili anket uygulanmıştır.

$\mathrm{Bu}$ çalışmada, alan araştırılması yapıldıktan sonra Gülnar ve Balcı (2011)'nın yabancı uyruklu öğrencilere uyguladığı anket sorularından faydalanılmıştır. Bahsi geçen anket formu, Şanlıurfa'da yaşayan Suriyeli sığınmacılara göre uyarlanmaya çalışılmış ve bu formlar farklı dört uzman tarafından incelenmiştir. Anket formlarının son halini almasıyla 100 kişi üzerinde pilot çalışma yapılmış; geçerli olan ve olmayan sorular yeniden değerlendirilmiştir. Pilot çalışmada dil problemi ile karşılaşılmıştır. Suriyeli sığınmacıların bir kısmının Türkçe yazılan bazı anket sorularını doğru anlayamadığı tespit edilmiştir. Bunun sonucunda anket formlarının büyük bir kısmı iki uzman tarafından Arapçaya çevrilmiş ve son halini alan anket soruları Şanlıurfa'da ikamet eden Suriyeli sığınmacılara uygulanmıştır.

$\mathrm{Bu}$ araştırma; kullanıldı $\breve{\mathrm{g}}$,

1) Sosyal medya platformlarının ne kadar ve daha fazla kimler tarafindan

2) Sosyal medya platformlarının sığınmacıların sosyalleşmesine katkısı,

3) Sığınmacıların topluma dahil olma sürecinde sosyal medya platformlarını nasıl, ne kadar ve hangi amaçla kullandıkları,

4) Sosyal medya platformlarını daha kullanılabilir ve yararlı hale getirilmesi için neler yapılabileceğine yönelik sorulara yanıt aramıştır. Bahsi geçen sorular Şanlıurfa'da ikamet eden Suriyeli sığınmacılar örnekleminde yanıt bulmuştur.

$\mathrm{Bu}$ çalışmada ortaya çıkan hipotezleri değerlendirmek maksadıyla, bağımsız örneklem $\mathrm{t}$ testi, eşleştirilmiş örneklem $\mathrm{t}$ testi, tek yönlü varyans analizi (ANOVA), bağımsız örneklem t testi ve korelasyon analizi kullanılmıştır.

Araştırmada; diğer medya araçlarıyla kıyaslandığında katılımcıların internet kullanma tutumlarının oldukça yüksek olduğu görülmektedir. Katılımcıların \%13,6 Türkiye'de olup bitenleri takip etmek, arkadaş edinmek, kişisel ihtiyaçlarını gidermek için hiç internet kullanmadığ $\% 16.0^{\star} 1$ haftada 5-6 gün geriye kalan $\% 45.5^{\prime} 1$ ise her gün düzenli olarak internet kullandığını belirtmiştir. Katılımcıların kendi ülkelerini takip etmek için internet kullanım 
oranlarına verdikleri cevaplar ise şu șekildedir. \%11.6'sı hiç, \%16.7'si haftada 1-2 gün, $\% 14.4$ haftada 3-4 gün, \%14.4 haftada 3-4 gün geriye kalan $\% 42.9$ ise her gün düzenli olarak kullanıyorum şeklinde yanıt vermiştir.

Yapılan araştırmadan da anlaşılmıştır ki, Türkiye'de yaşayan Suriyeli sığınmacılar sosyal medya platformlarından farklı amaçlar ile fazlasıyla faydalanmaktadır. Yine araştırmadan çıkarılan sonuca göre entegrasyon sürecinde sosyal medya platformları oldukça önemlidir ve etkili bir şekilde kullanılmalıdır. Araştırmaya göre, Suriyeli sığınmacıların önemli bir kısmı Türkçe bilmemektedir. Araştırmanın bir diğer sonucu ise Türkiye'de yaşayan Suriyeli sığınmacıların büyük bir çoğunluğunun eğitim seviyesinin düşük oluşudur. Sığınmacıların ülkelerine geri dönmeyeceğini varsayarsak sığınmacıların eğitimi konusunda yatırım yapmanın önemi bir kez daha anlaşılacaktır. Sığınmacıların eğitiminde sosyal medyanın önemli rol oynayabileceği düşünülmektedir.

Katılımcıların Türkçe dil seviyelerine bakıldığında sığınmacıların Türkçe dil yeterliliklerine ait aritmetik ortalama değerleri $=2,94$ ile $=3,27$ arasında değişmektedir. $\mathrm{Bu}$ sonuçlarda bize Şanlıurfa'da yaşayan Suriyeli sığınmacıların Türkçe yeterliliklerinin orta düzeyde olduğunu göstermektedir.

Çalışmadan anlaşılacağı gibi farklı amaçlar ile sığınmacılar, sosyal medyadan faydalanmaktadır. Kitle iletişim araçlarından en fazla tercih edilen ise internettir. Araştırmada, Suriyeli sığınmacıların entegrasyon sürecinde en fazla zorlandıkları durumun arkadaş edinmek ve sosyal topluluklara katılmak olduğu belirlenmiştir. Bu durumun birçok etkisi vardır; Türkçe konuşamama, kültür farkı, kendi aileleri akrabaları ile yaşama ve daha fazla kendi ülkesinin insanları ile zaman geçirme. Diğer yandan sosyal medyanın en önemli işlevleri arasında arkadaş edinme ve sosyalleşmenin geldiğini söylemek mümkündür. Sosyal medya iletişiminin yüz yüze iletişimden daha kolay ve daha cesaret verici olduğunu da düşünürsek, sığınmacıların yaşadığı arkadaş edinememe ve sosyalleşememe problemlerinin sosyal medya aracılığı ile önemli ölçü de aşılacağı düşünülmektedir.

İletişim ve sosyal olarak araştırmadan elde edilen veriler değerlendirildiğinde;

Katılımcıların kendi dillerinde konuşma sıklıkları, Türkçe konuşma sıklıklarında daha fazladir.

Katılımcıların kendi milletlerine ait kültürel etkinliklere katılım sıklığı Türk kültürel etkinliklerine katılım sıklıklarından daha fazladır.

Katılımcıların kendi kimliğine ait bireyler ile iletişim kurma sıklığı, ev sahibi bireyler ile iletişim kurma sıklığından daha yüksektir.

$\mathrm{Bu}$ sonuçlar değerlendirildiğinde Türkiye'de yaşayan Suriyeli sığınmacılar Türk kültürünü yaşamaktan, daha fazla kendi kültürlerini yaşamaktadır. Bunun sebebinin ise bölgede yaşayan Suriyeli sığınmacıların topluluklar halinde yaşamaları, toplumun içine girmektense kendi halkından fazlasıyla bulunan insanlarla iletişime geçmesi, alışverişlerini genelde kendi aralarında yapmaları gibi birçok sebebin olduğu düşünülmektedir.

Günümüzde sosyal medyanın konumu düşünüldüğünde ülkemize yeni gelen insanların entegrasyonu açısından oldukça önemli olduğu görülecektir. Sosyal medya platformlarında otomatik dil çevirisinin olmasının entegrasyona katkı sağlayacağı öngörülmektedir. Sığınmacıların sosyal medya kullanımı ve entegrasyonları açısından yapılacak araştırmalara kaynak olmayı amaçlayan bu çalışma, Türkiye'de en fazla Suriyeli sığınmacıya misafirlik yapan illerden biri olan Şanlıurfa'da yürütülmüş olması dolayısıyla önemli görülmektedir. 


\section{Kaynakça}

Aksakal, T. (2015). Etkili kamusal halkla ilişkiler bağlamında sosyal medya kullanımı ve Türkiye'de Youtube'nin kapatılması örneği. A. Büyükaslan ve A. M. Kırık (Ed.) içinde, Sosyal medya araştırmaları 1, 159-190. Konya: Çizgi Kitapevi.

Balle, F. ve Eymery, G. (1991). Yeni medyalar. (M. S. Şakiroğlu, Çev.) İstanbul: İletişim Yayınları.

Boyd, M. D. and Ellison, N. B. (2007). Social network sites: History and Scholarship. Journal of Computer-Mediated Communication, 13(1), 210-230.

Ellison, N. B., Steinfield, C. and Lampe, C. (2007). The benefits of Facebook "friends:" social capital and college students' use of online social network sites. Journal of Computer-Mediated Communication, 12(4), 1143-1168.

Erdal, C. (2013). Sosyal medya ve 'paylaşım kültürü'. C. Bilgili ve G. Şener (Ed.) içinde, Medya ve ăg kültürü-2, 55-68. İstanbul: Ege Basım.

Güçdemir, Y. (2012). Sanal ortamda iletişim bir halkla ilişkiler perspektifi. İstanbul: Derin Yayınları.

Güllüpınar, F. (2012). Göç olgusunun ekonomi-politiği ve uluslararası göç kuramları üzerine bir değerlendirme. Yalova Sosyal Bilimler Dergisi, 2(4), 53-85.

Gülnar. (2011). Yabancı öğrencilerde kültürleşme ve medya kullanımı. Global Media Journal, 2(3), 51-68.

Gülnar, B. ve Balc1, Ş. (2011). Yeni medya ve küreselleşen toplum. Konya: Sebat Ofset Yayıncilik.

Gündüz, U. ve Engin, Y. (2016). Sosyal medya ve dijital kimlik algısı. A. Büyükaslan ve A. M. Kırık (Ed.) içinde, Sosyal medya araştırmaları 3, 43-60. Konya: Çizgi Kitapevi.

Güngör, N. (2013). İletişim kuramlar ve yaklaşımlar. Ankara: Siyasal Kitapevi.

Kara, T. (2013). Sosyal medya endüstrisi. İstanbul: Beta Yayıncılık.

Kara, T. (2015). Ello: Kapitalist çağın mahremiyet tehditine yeni bir alternatif mi? D. Yengin ve D. Yengin (Ed.) içinde, Sosyal medya araştırmaları, 469-494. İstanbul: Paloma Yayınevi.

Kuşay, Y. (2010). Sosyal medyanın gücü ve uygulama örnekleri. F. Aydoğan ve A. Akyüz (Ed.) içinde, İkinci medya çağında internet 61-92. İstanbul: Alfa Yayıncılık.

Kuzucanl1, G. ve Saygın, E. P. (2021). Pandemi (Covid-19) sürecinde özel hastanelerin hedef kitlelerine yönelik İnstagram paylaşımlarındaki değişim: Şanlıurfa örneği. M. (Michael) Kuyucu ve H. Çiftçi (Ed.) içinde, A'dan z'ye iletişim çalışmaları-1 163-185.

Önen, C., Güneş, G., Türeme, A. ve Ağaç, P. (2014). Bir mülteci kampında yaşayan Suriyelilerde depresyon ve anksiyete durumu. Akademik Sosyal Araştırmalar Dergisi, 2(6), 223-230.

Türk Kızılayı Göç ve Mülteci Hizmetleri Müdürlüğü, T. K. (2017). Göç ve istatistik raporu. Ankara: Türk Kızılayı Genel Müdürlüğü. 
Uluç, G. ve Yarc1, A. (2018). Sosyal medya kültürü. Dumlupınar Üniversitesi Sosyal Bilimler Dergisi 52, 88-102.

Zeria, A. (2011). Kültürel işbirliğinde çok kültürlülük ve kültürlerarası iletişim. E. Esen ve Z. Yazıcı (Ed.) içinde, Onlar bizim hemşehrilerimiz uluslararası göç ve hizmetlerin kültürlerarası açılımı 129-137. Ankara: Siyasal Kitapevi.

Araştırmacı Katkı Oranı: Gökhan Kuzucanlı \%60, Aytekin Can \%40 oranında katkı să̆lamıştır.

Destekleyen Kurum/Kuruluşlar: Herhangi bir kurum/kuruluştan destek alınmamıştır.

Çıkar Çatışması: Herhangi bir çıkar çatışması bulunmamaktadır. 